\title{
Flowering induction in mango tree: updates, perspectives and options for organic agriculture ${ }^{1}$
}

\author{
Adrielle Rodrigues Prates ${ }^{2}$, Patrícia Graosque Ulguim Züge ${ }^{3}$, \\ Sarita Leonel ${ }^{3}$, Jackson Mirellys Azevêdo Souza ${ }^{4}$, Jorgiani de Ávila ${ }^{3}$
}

\section{ABSTRACT}

The artificial flowering induction in mango tree is the most important crop management in mango orchards and requires greater attention from growers. The management involves three steps: stoppage of plant growth, branch maturation and flowering induction with nitrates. The first stage starts with the application of paclobutrazol to the soil. However, problems with the use of excessive concentrations are common and lead to the accumulation of residues in the soil. In addition, the use of paclobutrazol is not allowed in organic agriculture. Therefore, this review article aimed to compile information about the updates and efforts to solve these problems in conventional mango crops, as well as identify alternatives for its organic management. In conventional orchards, the application of fulvic acids in association with paclobutrazol, as an alternative to the single use of paclobutrazol, was identified as a way to improve the absorption of the product by plants and, consequently, reduce the concentrations and residues in the soil. Researches involving pruning, girdling, fertilization and irrigation should be developed as an alternative to the use of paclobutrazol for the organic crop system of mango cultivars in tropical and subtropical regions.

KEYWORDS: Plant regulators, sustainable cultivation, drought stress, mineral nutrition.

\section{INTRODUCTION}

Mango (Mangifera indica L.) belongs to the Anacardiaceae family and is a fruit of great importance in subtropical and tropical climates. Brazil is the 7th world's largest producer (1.8 million tons) (FAO 2020), standing out the states of Bahia, São Paulo and Pernambuco (IBGE 2017).

\section{RESUMO}

Indução ao florescimento em mangueira: atualidades, perspectivas e opções para o sistema orgânico

A indução ao florescimento artificial em mangueira é o manejo cultural mais importante em pomares e requer maior atenção dos produtores. O manejo envolve três etapas: paralisação do crescimento das plantas, maturação dos ramos e indução ao florescimento com nitratos. A primeira etapa começa com a aplicação de paclobutrazol ao solo. Porém, são comuns problemas com o uso de concentrações excessivas, que levam ao acúmulo de resíduos no solo. Além disso, o uso de paclobutrazol não é permitido na agricultura orgânica. Objetivou-se, neste artigo de revisão, compilar informações sobre as atualizações e esforços para solucionar esses problemas em lavouras convencionais de manga, bem como identificar alternativas para o seu manejo orgânico. Em pomares convencionais, a aplicação de ácidos fúlvicos em associação a paclobutrazol, como alternativa ao uso exclusivo de paclobutrazol, foi identificada como forma de melhorar a absorção do produto pelas plantas e, consequentemente, reduzir as concentrações e resíduos no solo. Pesquisas envolvendo poda, anelamento, fertilização e irrigação devem ser desenvolvidas como alternativa ao uso de paclobutrazol para o cultivo orgânico de cultivares de manga em regiões tropicais e subtropicais.

PALAVRAS-CHAVE: Reguladores vegetais, cultivo sustentável, estresse hídrico, nutrição mineral.

Mango production plays an important role in Brazil, as the country has an average share of $10 \%$ in global imports, in addition to being a big consumer (Xavier \& Penha 2021). Therefore, it is necessary to deepen the knowledge about mango production and appropriate management practices, in order to achieve a high yield associated with fruit quality.

\footnotetext{
${ }^{1}$ Received: Mar. 14, 2021. Accepted: July 01, 2021. Published: Aug. 04, 2021. DOI: 10.1590/1983-40632021v5168175.

${ }^{2}$ Universidade Estadual Paulista, Faculdade de Ciências Agronômicas, Departamento de Ciência Florestal, Solos e Ambiente, Botucatu, SP, Brasil.E-mail/ORCID: adrielle.prates@unesp.br/0000-0003-4259-7151.

${ }^{3}$ Universidade Estadual Paulista, Faculdade de Ciências Agronômicas, Departamento de Produção Vegetal, Botucatu, SP, Brasil. E-mail/ORCID: patricia.graosque@unesp.br/0000-0002-3607-1447; sarita.leonel@unesp.br/0000-0003-2258-1355; j.avila@unesp.br/0000-0001-5737-4271.

${ }^{4}$ Universidade Federal de Viçosa, Departamento de Agronomia, Viçosa, MG, Brasil. E-mail/ORCID: jackson.m.souza@ufv.br/0000-0003-2350-7114.
} 
The mango tree growth occurs in up to four annual vegetative flows, and the stoppage of the vegetative growth is necessary for the beginning of flowering and, then, later fruiting (Davenport 2007). Some endogenous factors such as hormones, genetic composition, carbohydrates and stress conditions, as well as the age of the buds, are crucial for a successful flowering (Cho et al. 2017).

The flowering phase requires the most attention throughout the development of mango trees, as it is capable of allowing the production to be staggered over the year, as well as preserving the fruit quality (Fonseca et al. 2018, Oliveira 2020).

Mango flowering may take over several months; thus, the beginning of flowering can be induced by environmental factors, mainly by temperature change, as well as management practices such as the use of growth regulator, pruning and irrigation (Oliveira et al. 2017, Souza et al. 2018, Oliveira 2020, Santiago et al. 2020). These methods are especially important when it comes to organic agriculture, where synthetic products are disregarded. Thus, the mango organic production becomes an important sustainable alternative, as opposing to the continuous applications of growth regulators in conventional flowering induction methods, which may contaminate soil and water resources (Cavalcante et al. 2020, Silva et al. 2017).

In Brazil, the organic fruit production has grown in recent decades, a fact that may be attributed to changes in consumption habits that have demanded higher quality food produced with social responsibility towards the environment. In this way, suppliers have bet on cleaner and more sustainable agriculture to meet such demand (Correia et al. 2015).

This review article aimed to analyze the flowering induction in mango tree, in order to identify more sustainable alternatives for its organic management.

\section{MANGO FLOWERING}

The mango cultivated in subtropical regions, as well as other fruit trees such as avocado, lychee (Saúco \& Menini 1987) and mandarin, show alternate bearing, presenting a pronounced yield in a year and low yield in the next year (Muñoz-Fambuena et al. 2011). The alternate bearing in mango trees is not fully understood. The accumulation and depletion of carbohydrates is one of the hypotheses, but the interaction between photoassimilates and florigen in flowering induction must also be considered (Das et al. 2019).

The mango flowering is controlled by cool temperatures in subtropical regions and by water stress along with temperature in the tropics. Factors such as genetic composition, stress condition and age of the shoots are important for a successful flowering (Cho et al. 2017). Mango flowering is also regulated by endogenous hormones (auxins, cytokinins and gibberellins) and carbohydrates production, that is, phytohormones from the plant metabolism for the development of floral and vegetative buds (SantosVillalobos et al. 2013). Gibberellins can stimulate the vegetative growth and inhibit flowering at higher concentrations, whereas they enable flowering at lower concentrations (Ramírez \& Davenport 2010).

Thus, in the floral induction technique, growth regulators are commonly used, as the application of these substances may interfere with the synthesis of gibberellin. This is a well-established practice in mango crops in Brazil. Quaternary compounds can block the gibberellin synthesis, including mepiquat chloride and chlormequat chloride, which inhibit the conversion of geranyl diphosphate to kaurene (Oliveira 2020). Nitrogen-containing cyclic compounds such as paclobutrazol (PBZ) and uniconazole and acylcyclohexanediones such as ethyl-trinexapac (TrixE) and prohexadione $\mathrm{Ca}$ (ProCa) are, therefore, able to block the final reactions of gibberellin synthesis (Oliveira 2020).

For carbohydrate contents, some studies suggested that the content decreases in the leaf, while it increases in the flower buds, due to the energy demand for the formation of inflorescence (SantosVillalobos et al. 2013, Oliveira et al. 2018).

\section{CONVENTIONAL MANAGEMENT OF MANGO FLOWERING INDUCTION}

In conventional mango crops, flowering is induced by the application of more than one substance, such as PBZ, potassium sulphate, etefhon and potassium, calcium and ammonium nitrates, since the management consists of three stages, being the first one characterized by stoppage of growth using plant regulators such as PBZ; the second related to branch maturation caused by the application of potassium sulphate and etefhon; and the third consisting of the catalyzing of floral induction by 
the application of nitrates. This method has boosted researches, in relation to compounds, concentration, season and application form (Oliveira et al. 2015).

Regarding the blocking of gibberellin synthesis in mango crops, the main substance used is PBZ, mainly in tropical regions, where it is a first step in floral management, causing the inhibition of branch growth and allowing the flowering phase (Mouco et al. 2011, Oliveira et al. 2018).

In semi-arid conditions, the application of PBZ in 'Palmer' mango inhibits the expansion of the meristematic cells of the stem apex, as well as induces the thickening of the apex and the accumulation of phenolic compounds, promoting the inhibition of gibberellin synthesis, which is related to the grouping of cells at the stem apex without its expansion (Oliveira et al. 2020). The phenolic compounds accumulated by the application of PBZ have the capacity to inhibit growth, due to the negative effects on cell division and along the cell, in addition to promote an increase in the flowering intensity of the mango tree (Srilatha et al. 2015).

For potassium sulphate $\left(\mathrm{K}_{2} \mathrm{SO}_{4}\right)$, the $\mathrm{K}$ and $\mathrm{N}$ ratio is interfered by the potassium ion, preventing the plant from continuing to vegetate, thus enabling the maturation of the branches and increasing the bud fertility (Silva \& Neves 2011). Nitrates may break bud dormancy, enabling flowering, since flowers are emitted after their application. In addition, the bud emergence of mature branches will depend on the nitrate concentration used, as well as the nitrate choice will depend on its cost and availability (Ramírez et al. 2010).

The branch maturation stage is crucial, since it influences the mango production and uniformity, requiring a high demand for carbohydrates and energy (Cavalcante et al. 2018). Besides that, this phase represents the most stressful time for plants, caused by temperature variations and water availability. In tropical regions, there is an irrigation decrease in the management of floral induction (Ramírez \& Davenport 2016, Mudo et al. 2020, Silva et al. 2020a, Silva et al. 2020b), causing a physiological stress that will affect the photosynthesis process. In addition to water stress, ethephon and potassium sulphate are applied to promote the branches maturation, making them suitable for flowering (Cavalcante et al. 2018), but this management may increase plant stress.

When referring to the application of PBZ, doses may vary among genotypes, since the greater their vegetative vigor, the higher the dose to be applied. Moreover, they are influenced by weather conditions and orchard age (Mouco et al. 2010, Oliveira et al. 2017).

Furthermore, the application of PBZ in conventional agriculture may be carried out by soil moisture or distributed to the canopy projection via fertigation system. The latter is more widespread and efficient than foliar application, especially after tree pruning pointers, that is, after the second flow growth rate (Oliveira 2020, Silva et al. 2020c), because PBZ is mainly transported via xylem. Currently, most researches seek to improve the efficiency of PBZ, since its absorption mechanism presents difficulties due to low water solubility and low mobility in the soil, which are reversibly linked to the vascular system of both the plant and soil (Silva et al. 2020c).

In a study with application of PBZ in 'Bourbon' and 'Rosa' mangoes, flowering uniformity and a higher yield than for 'Palmer' mango were observed with the same application management (Chatzivagiannis et al. 2014). Furthermore, the responses to the plant growth inhibitor application may vary with the nutritional status of the plant (Souza et al. 2018).

The application of PBZ in the irrigation system makes it an interesting alternative to reduce product and labor costs. There are positive reports of this method, which improved the 'Palmer' mango yield, when compared to the conventional application (i.e., via soil) (Souza et al. 2018). However, PBZ may contaminate both the soil and water resources after long-term applications (Silva et al. 2017). These residues may remain active for a long period of time in the soil, thus hindering the mango tree growth and development (Cavalcante et al. 2020).

Some alternatives to improve the PBZ absorption by roots and prevent soil contamination, thus minimizing environmental risks and reducing dosages, have been evaluated, such as the use of biostimulants, which are substances that have biological compounds or agents capable of acting directly or indirectly on plants (Silva et al. 2020a), improving their nutritional efficiency (Yakhin et al. 2017), what will influence the fruit quality and yield of mango trees.

There is a positive effect on the physiological and reproductive variables of 'Tommy Atkins' mangoes grown in the tropical semi-arid region, when applied a biostimulant composed of amino 
acids and yeast extract, during the branch maturation stage (Mudo et al. 2020). Similarly, biostimulant applications with seaweed extract (Ascophyllum nodosum) also provide an increase in the number of panicles and yield of 'Palmer' mango (Silva et al. 2020a).

In 'Keitt' mangoes, the use of fulvic acids, free amino acids or their joint application improve the absorption of PBZ by the plant, potentiating the growth inhibition and providing less accumulation of soil residues (Silva et al. 2020c). The use of fulvic acids and amino acids may increase the PBZ absorption rate, as they have the ability to form complexes with nutrients and other molecules, facilitating the entry into the plasma membrane by active transport (Castro \& Carvalho 2014).

Humic substances also induce the activity of $\mathrm{H}^{+}$-ATPase protons that are pumped to form ATP, which causes variation in the electrochemical potential, reducing the $\mathrm{pH}$ of the apoplast, making the cell wall more flexible and facilitating the root growth, especially the lateral roots, which are responsible for most the absorbed water and nutrients (Trevisan et al. 2010, Zandonadi et al. 2010), in addition to activating the ionic metabolism and the transport of different substances (Jannin et al. 2012).

In addition to studies with biostimulants, amino acids and humic substances, other alternatives have been sought over the years. Among the studied alternatives, it is theuniconazole (UCZ), which belongs to the group of triazoles and inhibits the precursors of gibberellin synthesis, as it prevents the conversion of kaurene into kaurenoic acid, thus reducing growth (Lima et al. 2016). UCZ is similar to PBZ, since it also loses efficiency by foliar application, while triazoles are more efficient by soil application, especially when they are in contact with the root system (Silva et al. 2014, Oliveira 2020). Silva et al. (2014) observed that the application of UCZ in the mango canopy projection promoted better results than the foliar application, resulting in a higher percentage of flowering and greater yield, without altering the fruit quality. However, the authors stressed that the technique requires a long-term study to observe all singular effects, especially in relation to possible environmental damage.

Metconazole, which is also another triazole, prevents the synthesis of gibberellins by inhibiting the action of cytochrome P450-dependent monooxygenases that catalyze the oxidative steps of ent-kaurene to ent-kaurenoic acid (Cavalcante et al. 2020). The same authors reported that further studies are needed to introduce such compound in the management of mango floral induction, as well as to assess its long-term effects.

\section{FLOWERING MANAGEMENT FOR ORGANIC AGRICULTURE}

Many mango producers have adhered to organic agriculture over the years, what has provided a good income. Besides that, this type of cultivation is considered a great investment.

In the Maniçoba region near Juazeiro (Bahia state, Brazil), 17 mango producers obtained organic certification in 2006, exporting 44 tons to Canada (Embrapa 2020).

For mango flowering induction, there is a lack of literature on alternatives to chemical products and joint management practices (before, during and after fruit production), in order to get flowering and production uniformity (Medina-Urrutia et al. 2011).

The adequate mango nutrition is crucial to maintain growth and accumulation of carbohydrates. In organic farms, the fertilizers used must be listed under the Brazilian legislation (Brasil 2014).

Potassium is one of the macronutrients that influence the fruit production and physicochemical quality (Carneiro et al. 2018). Potassium sulphate $\left(\mathrm{K}_{2} \mathrm{SO}_{4}\right)$ may be used in organic agriculture, since it is more efficient in mango production and yield, when compared to potassium chloride $(\mathrm{KCl})$ (Carneiro et al. 2017). In organic agriculture, another option to potassium sulphate is Sulpomag ${ }^{\mathrm{TM}}\left(22 \%\right.$ of $\mathrm{K}_{2} \mathrm{O}$, $18 \%$ of $\mathrm{MgO}$ and $22 \%$ of S) at $2 \%\left(20 \mathrm{~g} \mathrm{~L}^{-1}\right)$, to increase the carbohydrate content (Embrapa 2020).

In fertilization management, attention should be paid with regard to over-applying nitrogen fertilizer, as it can decrease flowering, since it can stimulate vegetative growth (Medina-Urrutia et al. 2011). Foliar nitrogen levels should not exceed $1.4 \%$ to avoid vegetative growth out of season, that is, after pruning and during flowering management (Ramírez \& Davenport 2010).

Integrated management practices with lower doses of nitrogen, phosphorus and potassium (NPK), combined with corral manure, vermicompost or mulch layer, considerably influence the availability of nutrients and soil carbon, thus improving fruit production (Kumari et al. 2020). 
The use of plant growth promoting rhizobacteria such as Burkholderia caribensis XV and Rhizobium sp. XXV also showed promising results, since it increased the mango trees growth and flowering, what was demonstrated by an increase in the values of morphometry, biochemistry and molecular parameters, as well as synchronized flowering (Santos-Villalobos et al. 2013).

In subtropical conditions, temperature is one of the most important factors in the flowering of mango trees. Low temperatures mediate the content of plant hormones during mango floral induction (Luo et al. 2019). The sex ratio is also affected by temperature, relative humidity and rainfall, in addition to the plant's endogenous factors. Moreover, germination and pollen viability are highly dependent on climate conditions, where low temperatures may have a negative impact on germination, tube growth, zygote formation and fruiting (Ramírez \& Davenport 2016).

Temperature plays an important role in inducing flowering in mango tree, since bud growth occurs under temperatures of approximately $10{ }^{\circ} \mathrm{C}$ at night and $20^{\circ} \mathrm{C}$ during the day, generating flower buds (Santos-Villalobos et al. 2013). The proportion of hermaphrodite flowers in mango trees is a varietal character; however, it may be influenced by temperature during the floral morphogenesis phase, influencing the fruiting percentage (Geetha et al. 2016).

The florigenic promoter in mango is synthesized in leaves during exposure to cold, with translocation to the buds through phloem, to stimulate floral induction (Ramírez \& Davenport 2010). Mango tree is adapted to a wide range of temperatures, since it is grown in tropical and subtropical conditions, being the ideal range 22 to $27{ }^{\circ} \mathrm{C}$, which is the most suitable for growth and development (Laxman et al. 2016). The accumulation of at least 350 hours of cold $\left(<20^{\circ} \mathrm{C}\right)$ during the development of the axillary buds is necessary for the initiation and differentiation of the floral bud (Sarkhosh et al. 2018).

For mango flowering induction, a certain number of mature leaves is necessary to perceive the environmental signal to induce genes, such as local flowering T. This gene is expressed in leaves adjacent to the floral bud and may be transported to the apical bud during the flowering stage (Das et al. 2019). Under subtropical conditions, only $1 / 4$ of the leaves per stem provided enough florigenic promoter to induce flowering in $95 \%$ of the initial lateral shoots. However, the same leaf area in tropical conditions only induced flowering up to $11 \%$ of the beginning of the side shoots, on average (Ramírez \& Davenport 2010).

In tropical conditions, irrigation management is extremely important to induce flowering. During the branch development period, the partial water deficit is responsible to contain the vegetative flows, inducing floral differentiation and, consequently, production (Fonseca et al. 2018). The irrigation that meets the crop needs must be carried out as soon as it initiates the first signs of flowering in the buds (Fonseca et al. 2020).

Cutting irrigation water in 'Ubá' mango by half induce higher percentages of flowering and fruit production per plant, that is, $30 \mathrm{~L} \mathrm{plant}^{-1}$ day $^{-1}$ for four months before flowering or during leaf development (Fonseca et al. 2018).

Pruning management may also influence flowering, since the development of the axillary bud may be triggered by removing the tip of the branches. The tip pruning, which is performed $10 \mathrm{~cm}$ above the last internode, may significantly improve flowering; however, it may prevent flowering when performed at a late time (Sarkhosh et al. 2018). Moreover, there is a difference between cultivars in terms of thermal requirements and pruning time to induce flowering.

The practice of girdling is quite common for fruit producers, and has also shown great outcomes in inducing flowering of mango trees. This practice causes a decrease in leaf nitrogen, what may affect the photosynthetic capacity of the plant in the long term (Urban \& Alphonsout 2007) and increase metabolites such as plant hormones, sugars and amino acids above the region where the cut is made, thus blocking the transport of sugars to the roots (Ghadage et al. 2017, Shivashankara et al. 2019).

The girdle size and implementation time also influence the flowering parameters, since a ring with $1.50 \mathrm{~cm}$ wide in secondary branches of mango tree provides a higher percentage of fruits fixation, increases the number of fruits per branch, yield and pulp weight and volume (Ghadage et al. 2017).

Fermented cow urine is an alternative in organic mango crops, since it fits as a biofertilizer that may be used in foliar applications at $7 \%$. It is recommended to apply it four times every seven days, in order to break bud dormancy and promote flowering (Embrapa 2020). 
In organic agriculture, it is ideal to use all tools available in synchrony with the crop demands, in order to obtain better outcomes. In Brazil, there are few studies on mango flowering induction in organic management; therefore, further studies on floral induction practices are needed in this system.

\section{CONCLUSIONS}

1. In conventional orchards, recent studies show that the application of fulvic acids in association with paclobutrazol, as an alternative to the single use of paclobutrazol, is a way to improve the absorption of the product by plants and, consequently, reduce the concentrations and residues in the soil;

2. In organic orchards under subtropical conditions, pruning and plant nutrition should be followed carefully. Girdling on the branches brings positive results and may be an alternative, especially for cultivars that present irregular flowering;

3. In tropical regions, it is essential to improve the flowering percentage, irrigation management (with partial drought stress being provided) and the adequate nutritional condition, with pruning being maintained.

\section{REFERENCES}

BRASIL. Instrução Normativa $n^{\circ} 17$, de 18 de julho de 2014. Dispõe sobre o regulamento técnico para os sistemas orgânicos de produção animal e vegetal. 2014. Available at: https://bit.ly/3ehX6Va. Access on: 25 Sep. 2020.

CARNEIRO, M. A.; LIMA, A. M. N.; CAVALCANTE, Í. H. L.; CUNHA, J. C.; RODRIGUES, M. S.; LESSA, T. B. da S. Soil salinity and yield of mango fertigated with potassium sources. Revista Brasileira de Engenharia Agricola e Ambiental, v. 21, n. 5, p. 310-316, 2017.

CARNEIRO, M. A.; LIMA, A. M. N.; CAVALCANTE, I. H. L.; SOUSA, K. S. M.; OLDONI, F. C. A.; BARBOSA, K. S. Production and quality of mango fruits cv. Tommy Atkins fertigated with potassium in semi-arid region. Revista Brasileira de Fruticultura, v. 40, n. 5, e034, 2018.

CASTRO, P. R. C.; CARVALHO, M. E. A. Aminoácidos e suas aplicações na agricultura. Piracicaba: ESALQ, 2014.

CAVALCANTE, Í. H. L.; SANTOS, G. N. F. dos; SILVA, M. A. da; MARTINS, R. S.; LIMA, A. M. N.; MODESTO, P. I. R.; ALCOBIA, A. M.; SILVA, T. R. S.; ARAUJO E AMARIZ, R. A.; BECKMANN-CAVALCANTE, M. Z.
A new approach to induce mango shoot maturation in Brazilian semiarid environment. Journal of Applied Botany and Food Quality, v. 91, n. 1, p. 281-286, 2018.

CAVALCANTE, Í. H. L.; SILVA, G. J. N.; CAVACINI, J. A.; AMARIZ, R. A.; FREITAS, S. T.; SOUSA, K. A. O.; SILVA, M. A.; CUNHA, J. G. Metconazole on inhibition of gibberellin biosynthesis and flowering management in mango. Erwerbs-Obstbau, v. 62, n. 1, p. 89-95, 2020.

CHATZIVAGIANNIS, M. A.; SÃO JOSÉ,A. B.; BOMFIM, M. P.; OLIVEIRA JUNIOR, M. X.; REBOUÇAS, T. N. H. Florescimento e produtividade de mangueira 'Boubon', 'Palmer' e 'Rosa' com uso de paclobutrazol. Revista Iberoamericana de Tecnología Postcosecha, v. 15, n. 1, p. 41-47, 2014.

CHO, L. H.; YOON, J.; AN, G. The control of flowering time by environmental factors. The Plant Journal, v. 90, n. 4, p. 708-719, 2017.

CORREIA, R. C.; ARAUJO, J. L. P.; SILVA, P. C. G. da. Socioeconomia. 2015. Available at: https://www.spo. cnptia.embrapa.br/conteudo?p_p_id=conteudoportlet_ WAR_sistemasdeproducaolf6_1ga1ceportlet\&p_p_ lifecycle $=0 \& p \_p \_s t a t e=$ normal\&p_p_mode $=v i e w \& p \_p$ col_id=column-1\&p_p_col_count=1\&p_r_p_76293187_ sistemaProducaoId=7743\&p_r_p_-996514994_ topicoId $=8289$. Access on: 20 Sep. 2020.

DAS, A.; GEETHA, G. A.; RAVISHANKAR, K. V.; SHIVASHANKARA, K. S.; ROY, T. K.; DINESH, M. $\mathrm{R}$. Interrelations of growth regulators, carbohydrates and expression of flowering genes (FT, LFY, AP1) in leaf and shoot apex of regular and alternate bearing mango (Mangifera indica L.) cultivars during flowering. Scientia Horticulturae, v. 253, n. 11, p. 263-269, 2019.

DAVENPORT, T. L. Reproductive physiology of mango. Brazilian Journal of Plant Physiology, v. 19, n. 4, p. 363-376, 2007.

EMPRESA BRASILEIRA DE PESQUISA AGROPECUÁRIA (Embrapa). Sistema orgânico de produção de manga para a região da Chapada Diamantina, Bahia. 2020. Available at: https://bit.ly/3ekw4N1. Access on: 20 Sep. 2020.

FONSECA, N.; COELHO, E. F.; VIEIRA, R. S. Déficit hídrico na indução do florescimento e do aumento da produtividade da mangueira 'Ubá em cultivo orgânico na região da Chapada Diamantina, Bahia. Cruz das Almas: Embrapa, 2018. (Comunicado técnico, 165).

FONSECA, N.; PÁDUA, T. R. P.; LEDO, C. A. S.; VIEIRA, R. S. Desempenho agronômico de variedades de mangueira em cultivo orgânico na Chapada Diamantina na Bahia. Cruz das Almas: Embrapa Mandioca e Fruticultura, 2020. (Boletim de pesquisa e desenvolvimento, 107). 
FOOD AND AGRICULTURE ORGANIZATION OF THE UNITED NATIONS (FAO). Faostat. 2020. Available at: http://www.fao.org/faostat/en/\#data/QC. Access on: 11 Sep. 2020.

GEETHA, G. A.; SHIVASHANKARA, K. S.; REDDY, Y. T. N. Varietal variations in temperature response for hermaphrodite flower production and fruit set in mango (Mangifera indica L.). South African Journal of Botany, v. 106, n. 5, p. 196-203, 2016.

GHADAGE, N. J.; PATIL, S. J.; KHOPADE, R. Y.; SHAH, N. I.; HIRAY, S. A. Effect of time and width of girdling on flowering and yield of mango (Mangifera indica L.) cv. Alphonso. International Journal of Chemical Studies, v. 5, n. 6 , p. 1580-1583, 2017.

INSTITUTO BRASILEIRO DE GEOGRAFIA E ESTATÍSTICA (IBGE). CensoAgro. 2017. Available at: https://bit.ly/3emQLYG. Access on: 09 Sep. 2020.

JANNIN, L.; ARKOUN, M.; OURRY, A.; LAÎNÉ, P.; GOUX, D.; GARNICA, M.; FUENTES, M.; FRANCISCO, S. S.; BAIGORRI, R.; CRUZ, F.; HOUDUSSE, F.; GARCIA-MINA, J.-M.; YVIN, J.-C.; ETIENNE, P. Microarray analysis of humic acid effects on Brassica napus growth: involvement of N, C and S metabolisms. Plant and Soil, v. 359, n. 1-2, p. 297-319, 2012.

KUMARI, R.; KUNDU, M.; DAS, A.; RAKSHIT, R.; SAHAY, S.; SENGUPTA, S.; AHMAD, M. F. Long-term integrated nutrient management improves carbon stock and fruit yield in a subtropical mango (Mangifera indica L.) orchard. Journal of Soil Science and Plant Nutrition, v. 20, n. 2, p. 725-737, 2020.

LAXMAN, R. H.; ANNAPOORNAMMA, C. J.; BIRADAR, G. Mango. In: RAO, N.; SHIVASHANKARA, K.; LAXMAN, R. (ed.). Abiotic stress physiology of horticultural crops. New Delhi: Springer, 2016. p. 169181.

LIMA, G. M. D. S.; PEREIRA, M. C. T.; OLIVEIRA, M. B.; NIETSCHE, S.; MIZOBUTSI, G. P.; PÚBLIO FILHO, W. M.; MENDES, D. S. Floral induction management in 'Palmer' mango using uniconazole. Ciência Rural, v. 46, n. 8, p. 1350-1356, 2016.

LUO, C.; YU, H. X.; FAN, Y.; ZHANG, X. J.; HE, X. H. Research advance on the flowering mechanism of mango. Acta Horticulturae, v. 1244, n. 1, p. 17-22, 2019.

MEDINA-URRUTIA, V. M.; VÁZQUEZ-GARCÍA, M.; VIRGEN-CALLEROS, G. Organic mango production in Mexico: status of orchard management. Acta Horticulturae, v. 894, n. 1, p. 255-263, 2011.

MOUCO, M. A. C.; ONO, E. O.; RODRIGUES, J. D. Inibidores de síntese de giberelinas e crescimento de mudas de mangueira 'Tommy Atkins'. Ciência Rural, v. 40, n. 2, p. 273-279, 2010.

MOUCO, M. A. D. C.; ONO, E. O.; RODRIGUES, J. D. Controle do crescimento vegetativo e floração de mangueiras cv. Kent com reguladores de crescimento vegetal. Revista Brasileira de Fruticultura, v. 33, n. 4, p. 1043-1047, 2011.

MUDO, L. E. D.; LOBO, J. T.; CARREIRO, D. D. A.; CAVACINI, J. A.; SILVA, L. D. S.; CAVALCANTE, Í. H. L. Leaf gas exchange and flowering of mango sprayed with biostimulant in semi-arid region. Revista Caatinga, v. 33, n. 2, p. 332-340, 2020.

MUÑOZ-FAMBUENA, N.; MESEJO, C.; GOZÁLEZMAS, M. C.; PRIMO-MILLO, E.; AGUSTÍ, M.; IGLESIAS, D. J. Fruit regulates seasonal expression of flowering genes in alternate-bearing 'Moncada' mandarin. Annals of Botany, v. 108, n. 3, p. 511-519, 2011.

OLIVEIRA, G. P. Uso do paclobutrazol na produção de manga. Research, Society and Development, v. 9, n. 7, e939975183, 2020.

OLIVEIRA, G. P.; SIQUEIRA, D. L. D.; SALOMÃO, L. C. C.; CECON, P. R.; MACHADO, D. L. M. Paclobutrazol and branch tip pruning on the flowering induction and quality of mango tree fruits. Pesquisa Agropecuária Tropical, v. 47, n. 1, p. 7-14, 2017.

OLIVEIRA, G. P.; SIQUEIRA, D. L.; CECON, P. R.; SALOMÃO, L. C. C. Teores de carboidratos em mangueira 'Ubá' submetida a diferentes doses de paclobutrazol. Revista de Ciências Agrárias, v. 41, n. 3, p. 749-756, 2018.

OLIVEIRA, M. B.; FIGUEIREDO, M. G. F.; PEREIRA, M. C. T.; MOUCO, M. A. do C.; RIBEIRO, L. M.; MERCADANTE-SIMÕES, M. O. Structural and cytological aspects of mango floral induction using paclobutrazol. Scientia Horticulturae, v. 262, e109057, 2020.

OLIVEIRA, M. B.; PEREIRA, M. C. T.; MIZOBUTSI, G. P.; MAIA, V. M.; SILVA, J. F.; OLIVEIRA, J. A. A.; COSTA, I. J. S.; NIETSCHE, S.; SANTOS, E. F.; MOUCO, M. A. C. Paclobutrazol and tip pruning in the management of 'Palmer' mango trees in the semi-arid region of Brazil. Acta Horticulturae, v. 1075, n. 1, p. 149156, 2015.

RAMÍREZ, F.; DAVENPORT, T. L. Mango (Mangifera indica L.) flowering physiology. Scientia Horticulturae, v. 126, n. 2, p. 65-72, 2010.

RAMÍREZ, F.; DAVENPORT, T. L. Mango (Mangifera indica L.) pollination: a review. Scientia Horticulturae, v. 203, n. 6, p. 158-168, 2016.

RAMÍREZ, F.; DAVENPORT, T. L.; FISCHER, G. The number of leaves required for floral induction 
and translocation of the florigenic promoter in mango (Mangifera indica L.) in a tropical climate. Scientia Horticulturae, v. 123, n. 4, p. 443-453, 2010.

SANTIAGO, E. J. P.; FREIRE, A. D. S.; CUNHA, A. L. X.; CANTALICE, J. R. B.; MOUCO, M. D. C.; CUNHA FILHO, M.; SILVA, F. G.; SILVA, A. S. A.; OLIVEIRA, G. M. Caracterização de altas temperaturas e identificação de épocas suscetíveis à estenospermocarpia em mangas Palmer. Research, Society and Development, v. 9, n. 7, e383973734, 2020.

SANTOS-VILLALOBOS, S.; FOLTER, S.; DELANOFRIER, J.; GÓMEZ-LIM, M.; GUZMÁN-ORTIZ, D. Growth promotion and flowering induction in mango (Mangifera indica L. cv "Ataulfo") trees by burkholderia and rhizobium inoculation: morphometric, biochemical, and molecular events. Journal of Plant Growth Regulation, v. 32, n. 3, p. $615-627,2013$.

SARKHOSH, A.; MCCONCHIE, C.; KHADIVI, A. The effects of different tip-pruning times on flowering, yield, and maturity of two mango cultivars in subtropical climate of northern territory (Katherine region) from Australia. Scientia Horticulturae, v. 234, n. 8, p. 140145, 2018.

SAÚCO, V. G.; MENINI, U. G. El litchi y su cultivo. Rome: FAO, 1987.

SHIVASHANKARA, K. S.; GEETHA, G. A.; ROY, A. T. $\mathrm{K}$. Influence of girdling on flower sex ratio, biochemical constituents, and fruit set intensity in mango (Mangifera indica L.). Biologia Plantarum, v. 63, n. 1, p. 432-439, 2019.

SILVA, J. A. L.; NEVES, J. A. Combinação do paclobutrazol, sulfato de potássio e etefon na indução floral da mangueira cv. Tommy Atkins. Comunicata Scientiae, v. 2, n. 1, p. 18-24, 2011.

SILVA, K. K. A.; ONO, E. O.; MOUCO, M. A. C.; SILVA, G. J. N.; SOUZA, R. J. M.; SILVA, N. C.; SILVA, R. C. B. Uniconazole no florescimento e produção da mangueira (Mangifera indica L.) cv. Palmer. Revista Magistra, v. 26, n. 4, p. 507-517, 2014.

SILVA, L. S.; SILVA, P. T. D. S.; CAVALCANTE, Í. H. L. Impact of fulvic acid and free amino acids on paclobutrazol absorption by 'Keitt' mango. Ambiente e Água, v. 15, n. 4, p. 1-12, 2020c.

SILVA, M. A. D.; CAVALCANTE, Í. H.; MUDO, L. E.; PAIVA NETO, V. B. D.; CUNHA, J. G. D. Biostimulant alleviates abiotic stress of mango grown in semiarid environment. Revista Brasileira de Engenharia Agrícola e Ambiental, v. 24, n. 7, p. 457-464, 2020a.

SILVA, M. M. L.; RUFINI, J. C. M.; FAGUNDES, M. C. P.; MAIA, V.; PEREIRA, A. C. P.; SANTANA JÚNIOR, P. A.; SOUZA, W. G. Effect of carbohydrate content on shoot maturation and yield of Palmer mango submitted to potassium fertilization and biostimulant. Research, Society and Development, v. 9, n. 9, e888997948, 2020b.

SILVA, P. T. S.; SOUZA, L. S. S.; RODRIGUES NETA, C.; MOUCO, M. A.; SIMÕES, W.; FERRAZ, A. Análise de paclobutrazol em solos de áreas cultivadas com diferentes variedades de mangueira no Vale do São Francisco empregando QuEcHers e CLAE. Scientia Plena, v. 13, n. 9, p. 1-9, 2017.

SOUZA, M. A.; SIMÕES, W. L.; MESQUITA, A. C.; MOUCO, M. A. C.; CAVALCANTE, B. L. S.; GUIMARÃES, M. J. M. Manejo da quimigação para indução floral da mangueira 'Palmer' no submédio do Vale do São Francisco. Irriga, v. 23, n. 3, p. 442-453, 2018.

SRILATHA, V.; REDDY, Y. T. N.; UPRETI, K. K.; JAGANNATH, S. Pruning and paclobutrazol induced vigour, flowering and hormonal changes in mango (Mangifera indica L.). The Bioscan, v. 10, n. 1, p. 161-166, 2015.

TREVISAN, S.; PIZZEGHELLO, D.; RUPERTI, B.; FRANCIOSO, O.; SASSI, A.; PALME, K.; QUAGGIOTTI, S.; NARDI, S. Humic substances induce lateral root formation and expression of the early auxin-responsive IAA19 gene and DR5 synthetic element in Arabidopsis. Plant Biology, v. 12, n. 4, p. 604-614, 2010.

URBAN, L.; ALPHONSOUT, L. Girdling decreases photosynthetic electron fluxes and induces sustained photoprotection in mango leaves. Tree Physiology, v. 27, n. 3, p. 345-52, 2007.

XAVIER, L. M.; PENHA, T. A. M. O desempenho das exportações da manga no Brasil: uma análise de constant market share. Revista Análise Econômica e Politicas Públicas, v. 1, n. 1, p. 66-88, 2021.

YAKHIN, O. I.; LUBYANOV, A. A.; YAKHIN, I. A.; BROWN, P. H. Biostimulants in plant science: a global perspective. Frontiers in Plant Science, v. 7, e2049, 2017.

ZANDONADI, D. B.; SANTOS, M. P.; DOBBSS, L. B.; OLIVARES, F. L.; CANELLAS, L. P.; BINZEL, M. L.; OKOROKOVA-FAÇANHA, A. L.; FAÇANHA, A. R. Nitric oxide mediates humic acids-induced root development and plasma membrane $\mathrm{H}+$-ATPase activation. Planta, v. 231, n. 5, p. 1025-1036, 2010. 